\title{
トレッドミルに乗り移る際の運動調節
}

\section{Regulation of Step Length and Walking Velocity on Gait in Mounting a Treadmill}

下重 孝幸1)＼cjkstart谷 浩明2)

\author{
TAKAYUKI SHIMOJU, RPT ${ }^{1)}$, HIROAKI TANI, RPT ${ }^{2)}$ \\ 1) Kaigoroujinhokenshisetsu Onsenrihabilicenter Nijinooka: 93-1 Yada, Daigo-machi, Kuji-gun, Ibaraki 319-3552, Japan. \\ TEL +81 295-72-4564 \\ 2) Department of Physical Therapy, Faculty of Health Science Odawara, International University of Health and Welfare
}

Rigakuryoho Kagaku 22(1): 163-166, 2007. Submitted Sep. 11, 2006. Accepted Nov. 10, 2006.

\begin{abstract}
The objective of this research was to examine whether regulation of step length and walking velocity were observed as a timing control before mounting a moving surface, by-comparing mounting of a motorized treadmill with that of a stopped treadmill. Twenty healthy young adults participated in this experiment. We measured step length and walking velocity before mounting the motorized treadmill moving at a velocity of $1.8 \mathrm{~km} / \mathrm{h}$ and a stopped treadmill. Coefficient of variation (CV) was the index of variance of step length. We found that although there was no difference in walking velocity between a motorized treadmill and a stopped treadmill, CV increased on nearing the treadmill in mounting both the motorized treadmill and the topped treadmill $\left(\mathrm{F}_{4.190}=13.61, \mathrm{p}<0.01\right)$ and that $\mathrm{CV}$ increased at 2 steps before mounting the motorized treadmill $(\mathrm{p}<0.01)$. These results suggest two significant points. First, the gait in mounting the treadmill was affected by regulation of step length for transfer. Second, in mounting the motorized treadmill, regulation of step length was seen earlier than in mounting the stopped treadmill.
\end{abstract}

Key words: timing control, regulation of step length, treadmill

要旨 : 本研究の目的は, 動く支持面に乗り移るときのタイミング調節に歩幅調節, 歩行速度が関与しているかどうか を検討することである。そのために作動しているトレッドミル（作動課題）と停止しているトレッドミル（停止課題） に乗り移る課題の歩幅の変化を比較することとした。対象は健常成人 20 名とした。作動課題と停止課題それぞれにお いて, トレッドミルに乗り移る前の歩行時の歩幅, 歩行時間を計測した。歩幅のばらつきの程度は変動係数（CV）を 用いて示した。また歩行距離と歩行時間から歩行速度を求めた。結果, 作動課題, 停止課題いずれにおいてもトレッ ドミルに近づくにつれ歩幅のばらつきが有意に変化した $\left(\mathrm{F}_{4.190}=13.61, \mathrm{p}<0.01\right)$ 。特に作動課題では, トレッドミルに 乗り移る-2歩手前において歩幅のばらつきが有意に増加した（ $<0.01 ）$ 。歩行速度においては両課題間で差が認められ なかった。これらのことから, 床上からトレッドミルに乗り移る際の歩行は, 踏み切りの歩幅調節の影響を受けるこ とが確認され，作動課題ではより早期から歩幅調節が行われていることが確認された。

キーワード：タイミング調節，歩幅調節，トレッドミル

1) 介護老人保健施設＼cjkstart温泉リハビリセンター虹の丘：茨城県久慈郡大子町矢田93-1（テ319-3552）TEL 0295-72-6331

2) 国際医療福祉大学 小田原保健医療学部理学療法学科

受付日 2006年9月11日＼cjkstart受理日 2006年11月10日 


\section{I.はじめに}

高齢者の歩行において，転倒は大きなリスクである。 実際の日常生活の中では, 砂利道, 濡れた地面, 階段な ぞ高齢者の転倒を招くような歩行環境が数多く存在し ている。快適な移動手段として設置されているエスカ レータも, 動いている踏み面に乗り移るという動作が要 求されるため高齢者やバランス障害がある方にとって 安全に利用されているか疑問である。歩行中の環境と転 倒の危険性について調べたものには, 歩行障害物を想定 した跨ぎ動作についての研究1-4)やトレッドミル上歩行 において外乱刺激を加えることでその姿勢制御反応を 調べた研究5などが知られている。エスカレータに関す る研究は数少ないが，たとえば千葉ら ${ }^{6}$ は，障害者の屋 外活動範囲拡大を目的とし, 脳卒中片麻瘦患者を対象に エスカレーターの乗り移り動作の観察を行った。そこで 彼らは, エスカレータへの乗り移り動作ではどちらの下 肢を先に出した方が乗りやすいかを検討すること, 一側 下肢を踏み出してから他側を離すまでの時間 (両脚支持 期)を短縮させるような動作練習をすることが必要であ ると述べている。このように, エスカレータへの安全な 乗り移りに必要な要素を検討していくことは, 移動能力 が低下している人々の活動範囲を拡大させるためにも 意義のあることである。

エスカレータに乗る際には，一定のリズムで次々に 出てくる踏み面にタイミングを合わせて足を踏み出す 必要がある。健常者の乗り移り動作を観察しているとエ スカレータの前で一旦立ち止まらず, 歩行から続けて踏 み面に乗り移る場面をよく見かける。動く踏み面に対し て, 歩行しながらタイミングを合わせていると考えると どのような調節がなされているのか興味深い。そこで本 研究では, 実際にエスカレータを使用する前段階として トレッドミルを使用し, 動く支持面と動かない支持面に 乗り移ろうとする歩行時の歩幅と歩行速度に焦点を当 てて比較検討することとした。

\section{1. 対 象}

被験者は, 異常歩行を呈するような神経疾患や整形 外科疾患のない健常成人 20 名（男性 10 名, 女性 10 名）之 した。平均年齢は $23.9 \pm 3.5$ 歳, 平均身長は $165.0 \pm 7.4 \mathrm{~cm}$, 平均体重は $59.1 \pm 8.0 \mathrm{~kg}$ であった。なお, 研究の目的と 方法を十分に説明し, 同意を得た被験者のみが実験に参 加した。

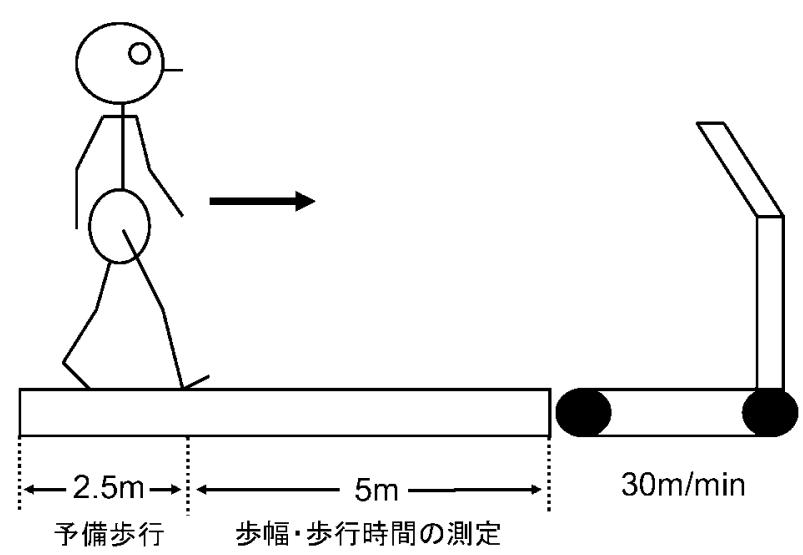

図1 歩行路の区分

\section{II. 方 法}

\section{1. 課題}

課題は, 支持面の動かない床上歩行路から, 作動して いるトレッドミルに乗り移る作動課題と停止している トレッドミルに乗り移る停止課題 (コントロール課題) の2課題とした。

\section{2. 手順}

トレッドミルはOG GIKEN社製UA-Rを使用し，その 手前に, パレット $(1,500 \mathrm{~mm} \times 900 \mathrm{~mm} \times 120 \mathrm{~mm})$ を縦 方向に 5 台並心゙ることでトレッドミルの高さに合わせた $7.5 \mathrm{~m}$ の歩行路を作成した。模式図を図1に示す。

被験者は歩行路の末端に立ち, 実験者からの開始の 掛け声で「できるだけ速い」速度の歩行を開始した。被 験者は7.5 mの床上歩行から続けてトレッドミルに乗り 移った。トレッドミル作動課題で3試行, 停止課題で3試 行の合計6試行を行い, 試行順序のランダム化を行った。 なお, 作動課題におけるトレッドミルの速度は分速 $30 \mathrm{~m}$ (時速 $1.8 \mathrm{~km})$ とした。

$7.5 \mathrm{~m}$ の歩行路のうち, はじめの $2.5 \mathrm{~m}$ ととの $5 \mathrm{~m}$ の間 にテープで境界線を引き, 被験者は $2.5 \mathrm{~m}$ を予備歩行し, 残りの $5 \mathrm{~m}$ の歩行において歩幅, 歩行時間を計測した。 歩幅は, 被験者の靴底（踵部）に白絵の具を染み込ませ たスポンジを装着しマーキングすることで,その距離を メジャーにより計測した。マーカーを見やすいようにす るため歩行路には緑色のビニールマットを敷いた。歩幅 の測定は, テープを跨いだ時点の歩幅から, 床上と卜 レッドミル間を跨ぐ歩幅より一歩手前の歩幅までの値 
を記録した。トレッドミルに乗り移る際，施行毎に歩幅 が大きくなったり小さくなったり変化が大きい場所ほ ど歩幅によるタイミング調節をしている可能性がある ため, 本研究では, ばらつきの程度を示す変動係数 (Coefficient of Variation : 以下CVとする)をパラメーター として算出した。作動課題, 停止課題それぞれ3回測定 した歩幅の実測值からCVを求めた。CVの算出に使用し た歩幅の值については, トレッドミルに踵接地した時の ステップを 0 歩, その直前の踵接地時のステップを -1 歩 として, -1 歩から -5 歩までの5歩分の值を用いた。歩 数の定義を図 2 に示す。また, 歩行時間はテープを跨い だ時点の踵接地から,トレッドミルに移った踵接地まで をストップウォッチにて計測し歩行速度を算出した。

\section{3. 統計解析}

CVにおいては, 統計処理ソフトウェア「Stat View」を 用いて二元配置分散分析を行い作動課題, 停止課題を比 較した。ステップ間の比較においては, 多重比較検定 （Tukey-Kramer）を行った。さらに, 各ステップの作動 課題と停止課題のCVについては統計ソフト「Excel」を 用いて対応のあるt検定で比較した。歩行速度において は，統計ソフト「Excel」を用いて対応のあるt検定を行 い, 作動課題, 停止課題を比較した。統計処理はいずれ

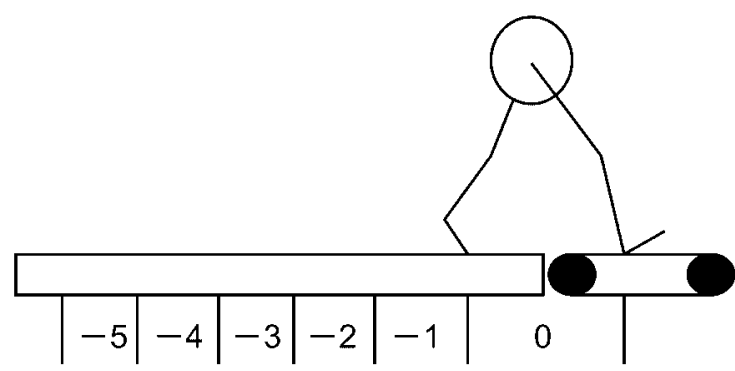

図2 歩数の定義

トレッドミルに踵接地した歩数を 0 歩, その直前の踵接地 時の歩数を-1歩として, -1 から-5歩までの5歩分の歩幅 值を使用した。
も有意水準 5\%未満とした。

\section{III. 結 果}

結果を表1に示す。表1は被験者20名のトレッドミル停 止課題と作動課題における平均のCV と歩行速度を示し ている。二元配置分散分析の結果, CV は作動課題, 停 止課題に関わらず同じような変化を示した $\left(\mathrm{F}_{4.190}=13.61\right.$, $\mathrm{p}<0.01 ） 。 ま た$ 多重比較検定の結果，作動課題，停止課 題の両者において -5 歩, -4 歩, -3 歩, -2 歩と -1 歩 の間に有意差が確認された $(\mathrm{p}<0.05)$ 。各ステップでの $\mathrm{CV}$ の比較では, 対応のあるt検定の結果, -2 歩目にお いて作動課題のCVが停止課題に比べ有意に大きいこと が確認された $(\mathrm{p}<0.01)$ 。歩行速度の比較では, 対応の あるt検定の結果，両課題間に差は見られなかった。

\section{IV. 考 察}

今回は，作動している時と停止している時の2パター ンのトレッドミルに乗り移る前の歩行に, 運動学的調節 としての歩行速度変化による調節, また歩幅調節が生じ るかどうかについて比較検討した。

今回の結果から, 両課題間に歩行速度の差は見られ ず, 動く支持面の影響を受けた速度の変化は示すことが できなかった。本研究で使用したトレッドミルでの課題 設定が歩行速度に変化を及ぼすまでに至らなかった可 能性があるが，今回測定した歩行速度は歩行距離 $5 \mathrm{~m}$ 内 の平均速度であったため, トレッドミルに近づくにつれ ての歩行速度の変化までは把握しきれていない。よっ て, 測定方法を検討し歩行中の速度変化にも注目するこ とで，より細かな歩行調節の評価を行う必要がある。

歩幅值のCVの比較においては, 両課題ともに同様の 変化を示し，-1歩の時点でCVが最大となった。トレッ ドミルの作動の有無に関わらず,トレッドミルに移る直 前でばらつきが大きくなるということは, 床上とトレッ ドミル間の境界部を適度な歩幅間隔で跨げるように歩 幅を大きくしたり小さくしたりする調節，いわゆる踏み

表1 トレッドミル停止課題と作動課題のCVと歩行速度の平均 $(\mathrm{n}=20)$

\begin{tabular}{|c|c|c|c|c|c|c|}
\hline \multirow[t]{2}{*}{ トレッドミル課題 } & \multicolumn{5}{|c|}{ step (単位: \%) } & \multirow[t]{2}{*}{ 歩行速度 (単位: $\mathrm{m} / \mathrm{sec})$} \\
\hline & -5 & -4 & -3 & -2 & -1 & \\
\hline 停止課題 & $3.0 \pm 0.3$ & $2.7 \pm 0.5$ & $2.3 \pm 0.3$ & $2.8 \pm 0.37$. & $5.4 \pm 0.8^{\dagger \dagger}$ & 1.44 \\
\hline 作動課題 & $2.7 \pm 0.5$ & $2.6 \pm 0.2$ & $2.9 \pm 0.4$ & $4.7 \pm 0.6\rfloor^{*}$ & $6.8 \pm 1.1^{\dagger \dagger}$ & 1.45 \\
\hline
\end{tabular}

$* *: p<0.01, \dagger: p<0.05$ 
切りに合わせるような歩幅調節を行っていたと考えら れる。踏み切りにおける歩幅調節の研究は, 走り幅跳び 等のスポーツ分野で多くなされている。走り幅跳びにお ける助走動作の研究7)でも, 踏切板に近づく助走終末段 階において歩幅のばらつきが確認されている。また, 踏 み切り直前に歩幅を大きくすることで踏み切り調節を していることも確認されている8)。

各ステップでのCVの比較においては, 作動課題の-2 歩目のCVが有意に大きかった。このことから, 作動し ているトレッドミルに乗り移る課題では歩幅のばらつ きがより早い時期から生じていることが確認された。中 村7) は, 走り幅跳びの助走動作の研究において, 踏切板 を踏み切ってから跳躍した場合は踏切板4歩手前から, また踏切板を踏み切ってからそのまま走り抜けた場合 は踏切板1歩手前から歩幅が調節されていることを確認 し, 歩幅調節がその後の運動パターンによって影響を受 けることを示唆した。森ら ${ }^{8)}$ は, 走り幅跳びにおける助 走の局面と踏み切りの局面のそれぞれの動作調節につ いて述べている。助走においては, 練習の繰り返しに よって得られた運動プログラムによって説明され, 踏み 切りにおいては, 視覚的な直接知覚によって歩幅の微調 整が行われていると説明している。つまり, 今回の研究 結果で示された歩幅のばらつき変化も床上・トレッドミ ル間に近づくまでは一定の歩行パターン (歩行という運 動プログラム) をとっており, 床上・トレッドミル間直 前では, 視覚的影響により歩幅調節を行っている可能性 が考えられる。また, 作動課題における歩幅調節が停止 課題よりも早い段階から行われるという結果も, 床上・ トレッドミル間を跨いだ後の状況が動いている支持面 という影響を受けていると考えられ, 乗り移る直前のス テップではなく, それより前のステップの段階から歩幅 調節を行い, よりスムースに床上とトレッドミルの間を
跨ぐ準備をしていたと考えられる。

本研究では, 歩行速度に変化が見られず, 歩幅による 調節をCVの変化によって考察したが，両課題における 歩行の調節については歩行開始時, あるいはトレッドミ ルへの接地時の左右足部の踏み出し順序や利き足の確 認, 床上歩行路とトレッドミル境界部への足部の接地の 有無, 歩行時の視線の位置などコントロールすべき要素 は数多く存在している。今後はそれらの要素や年齢の差 による変化, またトレッドミルの速度変化時の影響など を考慮し検討していく必要がある。

\section{引用文献}

1) 日下部良邦, 松永隆信, 喜久生明男・他 : またぎ動作におけ る床反力の検討一自由歩行との比較一. 整形外科バイオメカ ニクス, 1990, 12: 289-288.

2) 日下部良邦, 松永隆信, 糸数万正・他:またぎ動作における 床反力の検討一障害物の高さを変えた場合一. 整形外科バイ オメカニクス, 1991, 13: 125-129.

3) 日下部良邦：またぎ動作における床反力の検討. 岐阜大医 紀, 1994, 42: 292-303.

4) 渡部和彦: 高齢者歩行時の障害物への対応. 保健の科学, 1993, 35(2): 93-97.

5) 酒井美園, 大㴊修一, 柴 喜崇・他 : 歩行時の外乱刺激適応 課題にみられる姿勢制御反応一高齢者と若年者の筋反応パ ターンの比較一. 第18回バイオメカニズムシンポジウム, 2003, pp9-19.

6) 千葉かづ子, 秋山純和 : 脳卒中片麻痺患者のエスカレーター 使用に関する調查. 東北理学療法学, 1992, 4: 51-54.

7) 中村祥子: 走り幅跳びにおける助走動作の制御メカニズムと は? 一下肢の協応構造からの検討一. 運動学習研究会報告 集, 2002, 12: 10-16.

8) 森 司朗, 岡田僘笨 : 走り幅跳びにおける歩幅調節に関する 研究一踏切板の有無に関して一. 東京学芸大学紀要1部門, 1999, 50: 209-214. 